Article

\title{
High Tunnel Production of Tomatoes for Season Extension in Southeast Alabama
}

\author{
Bradley Reeder ${ }^{1}$, Wheeler Foshee ${ }^{1, *}$, Eugene Blythe ${ }^{1}$, Raymond Kessler ${ }^{1}$, Joseph Kemble ${ }^{1}$, \\ Edgar Vinson III ${ }^{1}$, William Dozier, Jr. ${ }^{1}$ and Larry Wells ${ }^{2}$ \\ 1 Department of Horticulture, Auburn University, 101 Funchess Hall, Auburn, AL 36849, USA; \\ reedebe@auburn.edu (B.R.); blythek@auburn.edu (E.B.); kessljr@auburn.edu (R.K.); \\ kembljm@auburn.edu (J.K.); vinsoed@auburn.edu (E.V.III); doziewi@auburn.edu (W.D.J.) \\ 2 Wiregrass Research and Extension Center, College of Agriculture, Auburn University, \\ Headland, AL 36345, USA; welllw@auburn.edu \\ * Correspondence: foshewg@auburn.edu; Tel.: +1-(334)-844-4862; Fax: +1-(334)-844-3131
}

Received: 12 October 2020; Accepted: 23 November 2020; Published: 1 December 2020

check for updates

\begin{abstract}
A series of experiments was conducted to evaluate variety selection and planting date for spring and fall season extension of tomato (Solanum lycopersicum L. (syn.: Lycoperisicon esculentum Mill.)) production in high tunnels in southeast Alabama. 'BHN 640', 'Florida 91', 'Sun Leaper', and 'Carolina Gold' were evaluated for early spring production in 2004. These varieties did not differ in total yield of marketable fruit; however, 'BHN 640' and 'Sun Leaper' produced higher early yields compared with the other varieties. 'BHN 640' and 'Florida 91' were evaluated for late-season extension in fall 2004. 'BHN 640' produced higher yields of large, medium, total marketable, and unmarketable fruit grades than 'Florida 91'. In a study conducted in early 2005, higher yields of marketable fruit were produced from the first planting date (31 January) compared with the final of four planting date (25 Mar.). In summary, results indicated that season extension of tomato production in high tunnels was possible, with harvests three weeks earlier in the spring and 12 weeks later in the fall compared with typical field harvest dates. These early yields can command prices from $\$ 3.30$ to $\$ 4.40 \mathrm{US}$ per $\mathrm{kg}$ of fruit.
\end{abstract}

Keywords: plasticulture; protected shelters; cold-tolerant tomatoes

\section{Introduction}

High tunnel production systems have received popular acceptance in production systems in Alabama over the last 15 years [1]. High tunnel production was initially developed in the U.S. by Otho Wells and his colleagues at the University of New Hampshire [2,3]. High tunnels have been shown to be an affordable technology for season extension in commercial crop production $[4,5]$.

Researchers at Pennsylvania State University (Penn State) conducted early investigations in production of tomatoes and snapdragons (Antirrhinum majus L. cv. Peoria) in high tunnels in the U.S., with results leading to establishment of the High Tunnel Research and Educational Facility in 1999 as a part of Penn State's Center for Plasticulture [6]. The Penn State system of high tunnel production is more closely related to field plasticulture [6] than the University of New Hampshire's high tunnel system [6]. Limited research has been conducted on use of high tunnels in the southeastern U.S. and none in the state of Alabama until studies were initiated in 2003 [7].

Typical planting dates for field-grown tomatoes in south Alabama are around 10 March. [8]. Drip-irrigated tomatoes with plastic mulch yield 1500 to 2000 11.25-kg boxes per acre. Spaw [9] reported that four- to five-week-old tomato transplants can be planted in a high tunnel four to five weeks earlier in the season than field plantings. Research has shown that a tomato crop will flower 
and produce a mature crop two to three weeks earlier in a high tunnel compared with a low tunnel (row cover) [4]. In Pennsylvania, tomatoes grown in high tunnels have shown a repeated problem with frost damage; therefore, heating with a portable propane heater has been advised [5]. Cold protection is required because tomato plants are damaged at temperatures below $10{ }^{\circ} \mathrm{C}$. In New Hampshire, high tunnels advance the maturity of tomatoes by 32 days compared with unprotected field-grown tomatoes [10]. Tomatoes grown in a high tunnel can produce up to $11.3 \mathrm{~kg}$ of fruit per plant [6]. According to Wells and Loy [11], if the width of a high tunnel exceeds $6 \mathrm{~m}$, then adequate ventilation is not attainable when outside temperatures rise above $30^{\circ} \mathrm{C}$. Additionally, a row spacing of $1.2 \mathrm{~m}$ allowed for 5 rows in a 6-m wide high tunnel, and required up to $4180 \mathrm{~L}$ of water per week [9].

Optimum growing temperatures for tomatoes are 25 to $30{ }^{\circ} \mathrm{C}$ during the day and 15.6 to $20^{\circ} \mathrm{C}$ at night. Temperatures $\geq 35^{\circ} \mathrm{C}$ or $\leq 10^{\circ} \mathrm{C}$ will halt growth and possibly cause damage [11]. Researchers at Penn State advise growers to be aware that early spring plantings of tomatoes in high tunnels can be damaged due to cold pockets and other similar microclimates [12]. Growers should be conservative in choosing early planting dates because, even if plants survive cold temperatures, physiological disorders can result from stress and will likely reduce yields [12].

High tunnels provide the potential of season extension, higher crop yield, and improved crop quality for both small-scale market gardens and larger scale farms [2]. A series of high tunnel experiments were conducted in south Alabama to evaluate variety selection and planting date for spring and fall season extension of tomato production in high tunnels in southeast Alabama. The goal of these seminal high tunnel tomato studies was to ascertain suitable varieties and to establish whether tomatoes could be gown in this system, which would allow for season extension.

\section{Materials and Methods}

Experiment 1. In the spring of 2004, an experiment was conducted to evaluate potential tomato varieties for a high tunnel production system in southeast Alabama. A single high tunnel ( $28.8 \mathrm{~m}$ long $\times 6.3 \mathrm{~m}$ wide) was constructed at the Wiregrass Research and Extension Center (WREC) in Headland, Alabama (lat. $31^{\circ} 19^{\prime} 20^{\prime \prime} \mathrm{N}, 85^{\circ} 29^{\prime} 1^{\prime \prime} \mathrm{W}$ ) utilizing the Penn State plan [6]. The high tunnel was situated with a north-south orientation, covered with a single layer of clear 6-mil polyethylene plastic, and constructed with roll-up sides for ventilation. For added ventilation, two automatic vents (Ken-Bar, Reading, MA, USA) that opened without the use of electricity were installed on the top of the high tunnel. During the study, the sides were rolled up for ventilation and to facilitate wind pollination. When the night-time temperature was predicted to be less than $7.2{ }^{\circ} \mathrm{C}$, the sides were rolled down by midafternoon. As the season progressed and temperatures increased, sides were left open longer in the day until days were warm enough (nighttime temperatures above $15.6^{\circ} \mathrm{C}$ ) to leave them open 24 h/day. End-walls were constructed to allow opening for access and use of equipment in the high tunnel. The soil type was a Lucy loamy sand (loamy, kaolinitic thermic Arenic Kandiudult).

Four tomato varieties ('Florida 91', 'BHN 640', 'Sun Leaper', and 'Carolina Gold') were sown in Canadian Growing Mix 2 (Conrad Fafard Inc., Agawan, MA, USA) in 48-cell trays on 13 February 2004 at the Plant Science Research Center at Auburn University, Alabama and allowed to grow for four weeks. Seedlings were fertilized once per week with a 20N-4.4P-16.6K water-soluble fertilizer (Peter's Water Soluble Plant Food 20-10-20; The Scotts Co, Marysville, OH, USA) at a rate of $265 \mathrm{mg} \cdot \mathrm{L}^{-1}$ N. Seedlings were hardened off for one week prior to field planting by decreasing watering intervals from twice daily to once daily for three days and discontinuing fertilization. The seedlings were then placed outside and allowed to wilt slightly, at which point they were watered lightly. Under these outdoor conditions, the seedlings were exposed to ambient conditions of wind and cool mornings; however, seedlings were never exposed to temperatures below $10^{\circ} \mathrm{C}$ while being hardened off.

Fertilizer (Red Fox Fertilizer, Dothan, AL, USA) was applied to the soil prior to bed formation inside the high tunnel at the rate of 81,61 , and $225 \mathrm{~kg} \cdot \mathrm{ha}^{-1}$ of N, P, and K, respectively (the recommended $30 \%$ to $40 \%$ of required $\mathrm{N}$ and $\mathrm{K}$ and $100 \%$ of required $\mathrm{P}$ based on soil test results from the Auburn University Soil Testing Lab). Then, 46-cm-wide raised beds were formed and 1.25-mil black plastic 
polyethylene mulch was laid on top of the beds utilizing a mulch bedder (Reddick Fumigants, Wilmington, NC, USA). The beds were $27 \mathrm{~m}$ long and $45 \mathrm{~cm}$ wide. Drip tape (T-Tape ${ }^{\circledR}, 1.71 \mathrm{~L} / \mathrm{min}$ per $30 \mathrm{~m}$; T-Systems International, San Diego, CA, USA) was laid underneath the plastic mulch for irrigation. The plants were irrigated as needed and fertigated weekly for the duration of the experiment through the drip tape with a Dosatron ${ }^{\circledR}$ (Clearwater, FL, USA) fertilizer injector, alternating $\mathrm{KNO}_{3}$ and $\mathrm{Ca}\left(\mathrm{NO}_{3}\right)_{2}$ as recommended by Kemble et al. (2004). During production, suckers were removed, and plants were tied to 1.2-m wooden stakes placed between every second plant [6]. Additional heat was supplied as needed by portable propane heaters.

The seedlings were transplanted into the high tunnel on a 45-cm spacing on 18 March. using a completely randomized design with four replications per variety. Data collection included fruit weight by grade (extra-large, large, medium, small, and culls), based on USDA standards [13], and number of fruit per plant. The first harvest was on 25 May, with two harvests per week continuing until 12 July. Harvested fruit was in the light-red to red stage according to USDA standards. The harvest season was separated into three harvest periods: early season included the first five harvest dates (25 May, 28 May, 1 June, 4 June, and 7 June; mid-season included the next five harvest dates (10 June, 14 June, 17 June, 21 June, and 24, June); and late-season harvest included the final five harvest dates (28 June, 30 June, 6 July, 8 July, and 12 July). Data were analyzed using the General Linear Model (GLM) procedure of SAS (SAS Institute, Cary, NC, USA) with Tukey's test $(p \leq 0.10)$ for multiple mean comparisons.

Experiment 2. In the fall of 2004, an experiment was conducted to compare the fruit yield of the varieties 'Florida 91' and 'BHN 640' grown in the high tunnel at the WREC. Seedlings were produced and hardened-off as described for Experiment 1. Beds in the high tunnel were prepared as in Experiment 1, except that 1-mil white plastic mulch was used to cover the beds. Nine plants of each variety were planted $45 \mathrm{~cm}$ apart in two rows using a completely randomized design on 31 Aug. Plants were drenched with Terraclor ${ }^{\circledR}$ (Crompton Manufacturing Co., Inc., Middlebury, CT, USA) at transplanting at the label rate for application to transplants. Plants were irrigated, fertigated, suckered, and tied to stakes as in Experiment 1. Supplemental heat was supplied by portable propane heaters as needed. There were seven harvest dates $(29$ November, 3 December 9 December, 6 December, 21 December, and 27 December 2004; 4 January 2005). Fruit were harvested in the light red-to-red stage, weighed, and counted according to USDA standards as in Experiment 1 . The two treatments (varieties) were arranged in a completely randomized design with three replications of each variety. Each row was divided into three plots to allow for a random planting of any tomato variety in any plot in each row. Each replication was planted in a single plot. Data was analyzed with $t$-test using the TTEST procedure of SAS.

Experiment 3. An experiment was conducted in the spring of 2005 at the WREC to determine optimum planting dates for early spring tomato production in the high tunnel at the WREC. 'BHN 640' and 'Florida 91' tomatoes were each planted on four dates (31 January, 17 February, 4 March., and 25 March.). Seedling production, bed preparation, irrigation, fertigation, sucker removal, and staking were handled as in Experiment 1. A split-plot design was utilized with planting date as the main plot factor and variety as the subplot factor. There were two main plots for each planting date and three plants of each variety randomized within each main plot. Data was collected as in Experiment 1 on seven harvest dates (24 May, 1 June, 7 June, 14 June, 21 June, 27 June, and 5 July) and analyzed with the MIXED procedure of SAS.

Experiment 4. A growth chamber study was conducted at the Plant Science Research Greenhouses at Auburn University, Alabama to determine suitable varieties for late fall and early spring high tunnel production in southeast Alabama. The varieties evaluated were 'BHN 640' and 'Florida 91', along with 10 cold-tolerant varieties typically grown in the field in the northwestern U.S. and Alaska: 'Glacier', 'Legend', 'Northern Delight', 'Oregon Spring', 'Polar Beauty', 'Santiam', 'Siletz', and 'Sub-Arctic Plenty'.

The 10 varieties were seeded on 7 April 2005 and seedlings were grown and hardened-off as in Experiment 1. Seedlings were transplanted into individual 11.4-L pots containing Canadian Growing Mix \#2 and placed into growth chambers on 11 May with one plant of each variety in each of three 
growth chambers. The experimental design was a randomized complete block design with growth chambers serving as blocks. Plants were spaced $30 \mathrm{~cm}$ apart within the growth chamber. A 1.2-m wooden stake was inserted into each pot and plants were tied to the stake as needed in order to maintain upright growth. Pollination was accomplished by vibrating the flower clusters with an electric toothbrush every two days. Once flowering had begun, plants were fertilized twice per week with a 20N-4.4P-16.6K water-soluble fertilizer (Peter's Plant Food 20-10-20 at a rate of $265 \mathrm{mg} \cdot \mathrm{L}^{-1} \mathrm{~N}$.

The growth chambers were programmed to provide a rise and fall of the temperature to the average maximum and minimum temperatures $\left(4.4\right.$ and $37.7^{\circ} \mathrm{C}$, respectively) based on data recorded with data loggers in the high tunnel at the WREC during Experiments 1 and 2. Temperature in the growth chamber was set to rise progressively for $12 \mathrm{~h}$ and drop progressively for $12 \mathrm{~h}$. Lights within the growth chamber operated for $12 \mathrm{~h} /$ day during the $12 \mathrm{~h}$ of temperature rise.

Fruit was harvested at the light red-to-red stage (according to USDA standards) between 15 July 2005 and 19 Aug. 2005. Harvested fruit was weighed and graded as in Experiment 1, with total weight by grade used for statistical analysis. Data was analyzed with the GLM procedure of SAS with Duncan's Multiple Range Test for multiple comparisons. The study was repeated in the summer of 2005 using the same varieties and experimental procedure, with seeding on 2 June, transplanting into containers and placement in the growth chambers on 9 July, and harvesting from 30 September 2005 to 2 November 2005.

Means were calculated using the MEANS procedure of SAS. Means comparisons were analyzed using the TTEST procedure of SAS. If variances were equal, the pooled method was used to determine significance. If variances were unequal, the Satterthwaite method was used to determine significance.

\section{Results}

Experiment 1 . There were no significant differences in total marketable weight (Table 1) or unmarketable weight (data not shown) of harvested fruit among the varieties tested. However, some differences in yield were detected when harvest was split into early, mid-, and late-season harvests (Table 2).

Table 1. Total yield of light-red to red marketable fruit ${ }^{\mathrm{z}}$ from four tomato varieties planted in a high tunnel at the Wiregrass Research and Extension Center (Headland, Alabama) on 18 March 2004 and harvested from 25 May to 12 July 2004 (Experiment 1).

\begin{tabular}{cc}
\hline Variety & Yield (kg/plant) \\
\hline 'BHN 640' & $5.01 \mathrm{a}^{\mathrm{z}}$ \\
'Carolina Gold' & $4.02 \mathrm{a}$ \\
'Florida 91' & $4.53 \mathrm{a}$ \\
'Sun Leaper' & $5.22 \mathrm{a}$ \\
\hline
\end{tabular}

${ }^{\mathrm{z}}$ Means followed by the same letter are not significantly different according to Tukey's test at $p \leq 0.10$.

Early in the harvest season, 'BHN 640' produced a higher total yield of marketable fruit than 'Carolina Gold' or 'Florida 91'. 'BHN 640' also produced a higher yield of extra-large fruit than 'Carolina Gold', and higher yields of large- and medium-sized fruit than 'Florida 91' or 'Carolina Gold'. 'Sun Leaper' was similar to 'BHN 640' in yields of total marketable, extra-large-, large-, and medium-sized tomatoes (Table 2).

There were differences in mid-season harvest with large- and medium-sized tomatoes (Table 2). 'BHN 640' yielded more large fruit than 'Carolina Gold' and 'Florida 91', and 'Sun Leaper' yielded more large fruit than 'Carolina Gold'. 'Sun Leaper' produced a greater yield of medium-sized fruit than the other three varieties. Overall yields were generally greater during this mid-season period (10 June to 24 June) than during the early season period; however, no significant differences were observed with extra-large fruit or total marketable fruit among the four varieties during the mid-season period. 
Table 2. Early, mid-, and late-season yield (by grade and total) of light-red to red marketable fruit from four tomato varieties planted in a high tunnel at the Wiregrass Research and Extension Center (Headland, Alabama) on 18 March 2004 and harvested from 25 May to 12 July 2004 (Experiment 1).

\begin{tabular}{ccccc}
\hline \multirow{2}{*}{ Fruit Grade ${ }^{*}$} & \multirow{2}{*}{ Variety } & \multicolumn{3}{c}{ Yield (kg/Plant) } \\
\cline { 3 - 5 } & & Early-Season & Mid-Season & Late-Season \\
\hline \multirow{2}{*}{ Extra-large } & 'BHN 640' & $0.78 \mathrm{a}$ & $2.33 \mathrm{a}$ & $0.56 \mathrm{~b}$ \\
& 'Carolina Gold' & $0.30 \mathrm{~b}$ & $1.89 \mathrm{a}$ & $0.72 \mathrm{ab}$ \\
& 'Florida 91' & $0.39 \mathrm{ab}$ & $2.28 \mathrm{a}$ & $1.00 \mathrm{a}$ \\
& 'Sun Leaper' & $0.68 \mathrm{ab}$ & $2.36 \mathrm{a}$ & $0.70 \mathrm{ab}$ \\
\hline \multirow{2}{*}{ Large } & 'BHN 640' & $0.14 \mathrm{a}$ & $0.69 \mathrm{a}$ & $0.35 \mathrm{a}$ \\
& 'Carolina Gold' & $0.08 \mathrm{bc}$ & $0.43 \mathrm{c}$ & $0.23 \mathrm{a}$ \\
& 'Florida 91' & $0.05 \mathrm{c}$ & $0.45 \mathrm{bc}$ & $0.24 \mathrm{a}$ \\
& 'Sun Leaper' & $0.13 \mathrm{ab}$ & $0.66 \mathrm{ab}$ & $0.32 \mathrm{a}$ \\
\hline \multirow{2}{*}{ Medium } & 'BHN 640' & $0.04 \mathrm{a}$ & $0.15 \mathrm{~b}$ & $0.08 \mathrm{a}$ \\
& 'Carolina Gold' & $0.01 \mathrm{~b}$ & $0.16 \mathrm{~b}$ & $0.07 \mathrm{a}$ \\
& 'Florida 91' & $0.01 \mathrm{~b}$ & $0.12 \mathrm{~b}$ & $0.07 \mathrm{a}$ \\
& 'Sun Leaper' & $0.05 \mathrm{a}$ & $0.26 \mathrm{a}$ & $0.07 \mathrm{a}$ \\
\hline Total marketable ${ }^{\mathrm{x}}$ & 'BHN 640' & $0.95 \mathrm{a}$ & $3.17 \mathrm{a}$ & $0.99 \mathrm{~b}$ \\
& 'Carolina Gold' & $0.37 \mathrm{bc}$ & $2.48 \mathrm{a}$ & $1.01 \mathrm{ab}$ \\
& 'Florida 91' & $0.36 \mathrm{c}$ & $2.85 \mathrm{a}$ & $1.30 \mathrm{a}$ \\
& 'Sun Leaper' & $0.83 \mathrm{ab}$ & $3.28 \mathrm{a}$ & $1.08 \mathrm{ab}$ \\
\hline
\end{tabular}

${ }^{z}$ U.S. Dept. of Agriculture standard grades for fresh tomatoes; ${ }^{\mathrm{y}}$ Means within a column and fruit grade followed by the same letter are not significantly different according to Tukey's test at $p \leq 0.10{ }^{\mathrm{x}}{ }^{\mathrm{X}}$ Total of extra-large, large, and medium fruits.

During the late-season harvest period, 'Florida 91' yielded more extra-large fruit and total marketable fruit than 'BHN 640', while producing yields similar to the other two varieties (Table 2). Yields were similar among all four varieties for large and medium fruit grades.

While there were no differences among the four varieties in total marketable yields for the entire season (Table 1), the early season differences were noteworthy. This study indicated that early production of tomatoes in a high tunnel system can be achieved in southeast Alabama. Premium prices for early tomatoes can be achieved by selecting 'BHN 640' and, to a lesser degree, 'Sun Leaper'. The total yield of fruit per plant for all varieties was very encouraging, with yields ranging from $4.02 \mathrm{~kg} /$ plant for 'Carolina Gold' to $5.22 \mathrm{~kg} /$ plant for 'Sun Leaper'. In this high tunnel, we were able to plant 60 plants per $27-\mathrm{m}$ row. An average of $5 \mathrm{~kg} / \mathrm{plant}$ of marketable fruit would yield $300 \mathrm{~kg}$ of fruit per row. Early season tomato prices in 2020 were on average US\$3.30 per kg [14], which would generate approximately US $\$ 995$ per row in gross returns; therefore, five rows within this single high tunnel ( $28.8 \mathrm{~m}$ long $\times 6.3 \mathrm{~m}$ wide) would generate approximately US $\$ 4975$ of gross income. Additionally, early season fruit ripened three weeks ahead of plants grown using conventional field production practices in the same region. Results suggest that high tunnel production of tomatoes has great potential for spring season production extension, especially considering the small amount of land required and the potential gross returns.

Experiment 2. Total yield of marketable fruit was $1.37 \mathrm{~kg} / \mathrm{plant}$ for 'BHN 640 ', greater than the $0.94 \mathrm{~kg} /$ plant for 'Florida 91' (Table 3). Only ripe fruit was harvested; mature green fruit, which would have added greatly to the reported yields, were evaluated in another study. The yield of 'BHN 640' was $46 \%$ higher than 'Florida 91' for marketable fruit. Totals yields for the season were all greater with 'BHN 640' than with 'Florida 91' for all grades, except the extra-large grade. There was no harvest date on which 'Florida 91' yielded more than 'BHN 640'. 
Table 3. Yield (by grade and totals) of light-red to red marketable and unmarketable fruit from 'BHN 640' and 'Florida 91' tomato varieties planted on 31 Aug. 2004 in a high tunnel at the Wiregrass Research and Extension Center (Headland, Alabama) and harvested on seven dates from 29 November 2004 to 4 January 2005 (Experiment 2).

\begin{tabular}{|c|c|c|c|c|c|c|c|c|c|}
\hline \multirow{2}{*}{ Fruit Grade $^{z}$} & \multirow{2}{*}{ Variety } & \multicolumn{8}{|c|}{ Harvest Date } \\
\hline & & $11 / 29$ & $12 / 3$ & $12 / 9$ & $12 / 16$ & $12 / 21$ & $12 / 27$ & $1 / 4$ & Total \\
\hline \multirow[t]{2}{*}{ Extra-large } & 'BHN 640' & $0.12 \mathrm{a}^{\mathrm{y}}$ & $0.08 \mathrm{a}$ & $0.05 a$ & $0.08 \mathrm{a}$ & $0.25 a$ & $0.17 \mathrm{a}$ & $0.28 \mathrm{a}$ & $0.95 a$ \\
\hline & 'Florida 91' & $0.05 a$ & $0.03 a$ & $0.01 \mathrm{a}$ & $0.06 a$ & $0.28 \mathrm{a}$ & $0.09 \mathrm{~b}$ & $0.29 a$ & $0.79 a$ \\
\hline \multirow[t]{2}{*}{ Large } & 'BHN 640' & $0.00 \mathrm{a}$ & $0.00 \mathrm{a}$ & $0.02 \mathrm{a}$ & $0.00 \mathrm{a}$ & $0.11 \mathrm{a}$ & $0.09 a$ & $0.09 a$ & $0.32 \mathrm{a}$ \\
\hline & 'Florida 91' & $0.00 \mathrm{a}$ & $0.00 \mathrm{a}$ & $0.00 \mathrm{~b}$ & $0.01 \mathrm{a}$ & $0.02 b$ & $0.03 b$ & $0.06 a$ & $0.13 b$ \\
\hline \multirow[t]{2}{*}{ Medium } & 'BHN 640' & $0.00 \mathrm{a}$ & $0.00 \mathrm{a}$ & $0.00 \mathrm{a}$ & $0.00 \mathrm{a}$ & $0.04 a$ & $0.04 \mathrm{a}$ & $0.01 \mathrm{a}$ & $0.09 a$ \\
\hline & 'Florida 91' & $0.00 \mathrm{a}$ & $0.00 \mathrm{a}$ & $0.00 \mathrm{a}$ & $0.00 \mathrm{a}$ & $0.01 \mathrm{~b}$ & $0.00 \mathrm{~b}$ & $0.00 \mathrm{a}$ & $0.02 b$ \\
\hline \multirow[t]{2}{*}{ Small } & 'BHN 640' & $0.00 \mathrm{a}$ & $0.00 \mathrm{a}$ & $0.00 \mathrm{a}$ & $0.00 \mathrm{a}$ & $0.00 \mathrm{a}$ & $0.01 \mathrm{a}$ & $0.00 \mathrm{a}$ & $0.02 \mathrm{a}$ \\
\hline & 'Florida 91' & $0.00 \mathrm{a}$ & $0.00 \mathrm{a}$ & $0.00 \mathrm{a}$ & $0.00 \mathrm{a}$ & $0.00 \mathrm{a}$ & $0.00 \mathrm{~b}$ & $0.00 \mathrm{a}$ & $0.00 \mathrm{~b}$ \\
\hline \multirow[t]{2}{*}{ Total marketable ${ }^{x}$} & 'BHN 640' & $0.12 \mathrm{a}$ & $0.09 \mathrm{a}$ & $0.08 \mathrm{a}$ & $0.08 \mathrm{a}$ & $0.40 \mathrm{a}$ & $0.30 \mathrm{a}$ & $0.39 a$ & $1.37 \mathrm{a}$ \\
\hline & 'Florida 91' & $0.05 \mathrm{a}$ & $0.03 a$ & $0.01 \mathrm{a}$ & $0.07 a$ & $0.32 \mathrm{a}$ & $0.13 b$ & $0.35 a$ & $0.94 b$ \\
\hline \multirow[t]{2}{*}{ Total unmarketable ${ }^{\mathrm{w}}$} & 'BHN 640' & $0.04 a$ & $0.01 \mathrm{a}$ & $0.01 \mathrm{a}$ & $0.05 a$ & $0.10 \mathrm{a}$ & $0.03 a$ & $0.09 a$ & $0.31 \mathrm{a}$ \\
\hline & 'Florida 91' & $0.02 \mathrm{a}$ & $0.00 \mathrm{a}$ & $0.00 \mathrm{a}$ & $0.03 a$ & $0.03 b$ & $0.05 a$ & $0.10 \mathrm{a}$ & $0.23 b$ \\
\hline
\end{tabular}

Marketable fruit weights for each harvest date revealed some differences (Table 3). On 9 December, the weight of large fruit was greater for 'BHN 640' than for 'Florida 91'. On 21 December, 'BHN 640' yields were greater for large, medium, and total unmarketable fruit weights than for 'Florida 91'. On 27 December, 'BHN 640 yields were greater than yields of 'Florida 91' for extra large, large, medium, small, and total marketable weights.

The first harvest date in this experiment was 29 November and the last harvest date was 4 January, which was rather extraordinary for a production system that involved the addition of heat only when the temperature was predicted to drop below $7.2{ }^{\circ} \mathrm{C}$ for an extended period of time within the high tunnel. It was during this period of the year that the price for tomatoes was high and we received as much as US $\$ 8.45 / \mathrm{kg}$ from a local restaurant, due in large part to hurricane-damaged Florida tomato crops. Results indicated that 'BHN 640' would be preferable to 'Florida 91' for late fall production of tomatoes in high tunnels for season extension in southeast Alabama.

Experiment 3. On 16 February and 17 February of 2005, strong wind gusts occurred for several hours, causing some damage to the high tunnel by tearing the plastic on one side of the structure during the night, leading to damage or death of some tomato plants. Reduced plant density affected the first and second planting dates since the third planting took place on 4 Mar. Harvest weights were adjusted to account for missing tomato plants from each wind event and analyzed with data weighted based on the number of surviving plants.

Planting date affected the total fruit yields of the two varieties in most of the harvest periods (Table 4). Fruit harvested during the first harvest week of 24 May came exclusively from the first (31 January) and second (17 February) planting dates. Planting date one (31 January) produced greater yields than planting date three (4 March.) and four (25 March.) in the second (31 May and 3 June), third ( 6 and 9 June), fourth (13 and 16 June), and fifth (20 and 24 June) harvest periods. 'BHN 640' produced greater marketable yields than 'Florida 91 ' in the third harvest period for the first and second planting dates. An interaction between planting date and variety factors was exhibited during the fourth harvest week. There were no significant differences noted in the seventh harvest (5 July). Overall, the total marketable yields for the entire season were significantly greater from the first planting date than from the last of the four planting dates. 
Table 4. Yield (by grade and total) of light-red to red marketable ${ }^{\mathrm{z}}$ fruit from seven harvest periods and total unmarketable fruit from 'BHN 640' and 'Florida 91' tomato varieties planted on four dates and grown in a high tunnel at the Wiregrass Research and Extension Center (Headland, Alabama) in winter/spring 2005 (Experiment 3).

\begin{tabular}{|c|c|c|c|c|c|c|c|c|c|}
\hline \multirow{2}{*}{$\begin{array}{l}\text { Planting Date } \\
\text { and Variety }\end{array}$} & \multicolumn{8}{|c|}{ Total Marketable Yield (kg/plant) ${ }^{\mathrm{z}}$} & \multirow[b]{2}{*}{$\begin{array}{c}\text { Total Unmrkt. } \\
\text { Yield (kg) }\end{array}$} \\
\hline & $5 / 24$ & $5 / 31,6 / 3$ & $6 / 6,6 / 9$ & $\begin{array}{l}6 / 13 \\
6 / 16\end{array}$ & $\begin{array}{l}6 / 20 \\
6 / 24\end{array}$ & $6 / 27$ & $7 / 5$ & $\begin{array}{c}\text { Total } \\
\text { Harvest }\end{array}$ & \\
\hline \multicolumn{10}{|l|}{$1 / 31$} \\
\hline 'BHN 640' & $0.08^{\mathrm{y}}$ & 0.93 & $1.14 *$ & 1.85 & 1.84 & $0.76^{*}$ & 1.15 & 7.51 & 0.72 \\
\hline 'Florida 91' & 0.00 & 0.67 & $0.83 *$ & 1.39 & 1.77 & $0.19 *$ & 1.07 & 5.62 & 0.79 \\
\hline Combined & $0.04 \mathrm{a}^{\mathrm{x}}$ & $0.80 \mathrm{a}$ & $0.99 a$ & $1.62 \mathrm{a}$ & $1.81 \mathrm{a}$ & $0.43 \mathrm{ab}$ & $1.11 \mathrm{a}$ & $6.56 a$ & $0.76 a$ \\
\hline \multicolumn{10}{|l|}{$2 / 17$} \\
\hline 'BHN 640' & 0.04 & 0.63 & 0.74 * & 1.30 & 1.05 & 0.57 & 1.19 & 5.60 & 0.85 \\
\hline 'Florida 91' & 0.08 & 0.34 & $0.22 *$ & 0.69 & 1.76 & 0.53 & 0.63 & 4.22 & 0.52 \\
\hline Combined & $0.06 a$ & $0.49 \mathrm{ab}$ & $0.48 \mathrm{ab}$ & $0.99 \mathrm{ab}$ & $1.40 \mathrm{ab}$ & $0.55 \mathrm{ab}$ & $0.91 \mathrm{ab}$ & $4.91 \mathrm{ab}$ & $0.69 \mathrm{ab}$ \\
\hline \multicolumn{10}{|l|}{$3 / 4$} \\
\hline 'BHN 640' & 0.00 & 0.02 & 0.27 & 0.56 & 1.15 & 0.84 & 1.26 & 4.12 & 0.41 \\
\hline 'Florida 91' & 0.00 & 0.00 & 0.07 & 0.50 & 0.87 & 0.59 & 1.27 & 3.29 & 0.22 \\
\hline Combined & $0.00 \mathrm{a}$ & $0.01 \mathrm{~b}$ & $0.17 \mathrm{~b}$ & $0.53 \mathrm{~b}$ & $1.01 \mathrm{~b}$ & $0.72 \mathrm{a}$ & $1.27 \mathrm{ab}$ & $3.71 \mathrm{ab}$ & $0.31 b$ \\
\hline \multicolumn{10}{|l|}{$3 / 25$} \\
\hline 'BHN 640' & 0.00 & 0.00 & 0.13 & 0.22 & 0.60 & 0.26 & 0.35 & 1.56 & 0.42 \\
\hline 'Florida 91' & 0.00 & 0.00 & 0.03 & 0.12 & 0.48 & 0.42 & 1.32 & 2.37 & 0.35 \\
\hline Combined & $0.00 \mathrm{a}$ & $0.00 \mathrm{~b}$ & $0.08 b$ & $0.17 \mathrm{c}$ & $0.54 \mathrm{~b}$ & $0.34 \mathrm{~b}$ & $0.83 b$ & $1.97 \mathrm{~b}$ & $0.39 \mathrm{ab}$ \\
\hline \multicolumn{10}{|l|}{ Significance ${ }^{\mathrm{w}}$} \\
\hline Planting date & NS & $* *$ & $* *$ & $* *$ & $* *$ & * & NS & $* *$ & $* *$ \\
\hline Variety & NS & NS & $* *$ & NS & NS & * & NS & NS & NS \\
\hline Date $\times$ variety & NS & NS & NS & NS & NS & * & NS & NS & NS \\
\hline $\begin{array}{l}\mathrm{z} \text { Extra-large, } \\
\text { tomatoes); } \\
\text { letter are sign } \\
\text { from the four } \\
p \leq 0.10 \text { based } \\
\text { based on F-tes }\end{array}$ & $\begin{array}{l}\text { ge, me } \\
\text { ans for } \\
\text { antly d } \\
\text { nting c } \\
\text { linea }\end{array}$ & $\begin{array}{l}\text { am, and } \\
\text { dividua } \\
\text { erent at } \\
\text { es withir } \\
\text { ontrasts }\end{array}$ & $\begin{array}{l}\text { mall ton } \\
\text { varieties } \\
\leq 0.10 \mathrm{~b} \\
\text { a colum } \\
\text { Effect }\end{array}$ & $\begin{array}{l}\text { toes }(b \\
\text { ithin a } \\
\text { ed on li } \\
\text { harvest } \\
\text { is not s }\end{array}$ & $\begin{array}{l}\text { d on U } \\
\text { lumn } \\
\text { ir cont } \\
\text { llowec } \\
\text { ificant }\end{array}$ & $\begin{array}{l}\text { Dept. } \\
\text { rvest) a } \\
\text { ts; }{ }^{x} \mathrm{Me} \\
y \text { the sa } \\
\text { (S) or si }\end{array}$ & $\begin{array}{l}\text { Agricul } \\
\text { planti } \\
\text { is for co } \\
\text { letter } \\
\text { ifficant }\end{array}$ & $\begin{array}{l}\text { date follo } \\
\text { ined yielc } \\
\text { not signifi } \\
\leq 0.10 \text { ( }^{*}\end{array}$ & $\begin{array}{l}\text { ades for fresh } \\
\text { d by the same } \\
\text { both varieties } \\
\text { tly different at } \\
\text { d } p \leq 0.05\left(^{* *}\right)\end{array}$ \\
\hline
\end{tabular}

Results from this experiment indicate that early planted tomatoes grown in a high tunnel system can produce good yields of marketable tomatoes; however, further investigation is needed to develop recommendations on planting date and suitable varieties. Although two major setbacks were experienced due to weather, harvest in the high tunnel began 16 days earlier than with local field-grown crops. Local growers in the area began picking fruit on 15 June (John Aplin, personal communication). With the price for fresh tomatoes being higher during this period, high tunnel production systems show promise for greater profit potential for growers.

Experiment 4. There were no significant differences for the total yields of extra-large fruit in the first experimental run, while 'BHN 640' and 'Florida 91' outperformed other varieties (except 'Legend') in the second run (Table 5). No significant differences were observed in the yield of large fruit in either run. 'Polar Beauty' and 'Santiam' produced yields of medium-sized tomatoes that were similar or greater than other varieties in run 1, while 'BHN 640', 'Polar Beauty', and 'Santiam' performed in a similar manner in run 2 . The overall yield of total marketable fruit was similar among all varieties in run 1, while yields from "BHN 640' and 'Florida 91' were similar or greater than other varieties in run 2. 'Glacier', 'Northern Delight', and 'Sub-Arctic Plenty' each produced $>400 \mathrm{~g}$ of small fruit in both run 1 and run 2, while other varieties produced less. 'Siletz' produced more culls than other varieties (except 'Legend') in run 1, while 'Santiam' produced more culls than other varieties in run 2. 'Oregon Spring' produced no fruit in either run. 
Table 5. Yield of light-red to red fruit by grade from 10 tomato varieties in growth chambers programmed to simulate average late-fall/early spring minimum/maximum temperatures and daylength (based on prior data from spring of 2005) in a high tunnel at the Wiregrass Research and Extension Center in Headland, Alabama (Experiment 4).

\begin{tabular}{|c|c|c|c|c|c|c|}
\hline \multirow{2}{*}{ Variety } & \multicolumn{6}{|c|}{ Yield (g) by Grade ${ }^{z}$} \\
\hline & Extra -Large & Large & Medium & Total Marketable ${ }^{y}$ & Small & Cull \\
\hline Run $1^{x}$ : & & & & & & \\
\hline 'BHN 640' & $75.7 \mathrm{a}^{\mathrm{w}}$ & $0.0 \mathrm{a}$ & $45.4 \mathrm{ab}$ & $121.1 \mathrm{a}$ & 75.7de & $0.0 \mathrm{~b}$ \\
\hline 'Florida 91' & $86.8 \mathrm{a}$ & $0.0 \mathrm{a}$ & $46.7 \mathrm{ab}$ & $133.5 \mathrm{a}$ & $44.1 \mathrm{e}$ & $0.0 \mathrm{~b}$ \\
\hline 'Glacier' & $0.0 \mathrm{a}$ & $0.0 \mathrm{a}$ & $17.6 \mathrm{ab}$ & $17.6 \mathrm{a}$ & $459.2 \mathrm{ab}$ & $32.7 \mathrm{~b}$ \\
\hline 'Legend' & $0.0 \mathrm{a}$ & $40.1 \mathrm{a}$ & $0.0 \mathrm{~b}$ & $40.1 \mathrm{a}$ & $0.0 \mathrm{e}$ & $128.7 \mathrm{ab}$ \\
\hline 'Northern Delight' & $0.0 \mathrm{a}$ & $0.0 \mathrm{a}$ & $0.0 \mathrm{~b}$ & $0.0 \mathrm{a}$ & $645.4 \mathrm{a}$ & $7.8 \mathrm{~b}$ \\
\hline 'Oregon Spring' & $0.0 \mathrm{a}$ & $0.0 \mathrm{a}$ & $0.0 \mathrm{~b}$ & $0.0 \mathrm{a}$ & $0.0 \mathrm{e}$ & $0.0 \mathrm{~b}$ \\
\hline 'Polar Beauty' & $77.1 \mathrm{a}$ & $45.2 \mathrm{a}$ & $191.5 \mathrm{a}$ & $313.8 \mathrm{a}$ & 301.7bcd & $57.0 \mathrm{~b}$ \\
\hline 'Santiam' & $0.0 \mathrm{a}$ & $44.6 \mathrm{a}$ & $111.6 \mathrm{ab}$ & $156.2 a$ & $222.6 \mathrm{cde}$ & $75.3 b$ \\
\hline 'Siletz' & $68.0 \mathrm{a}$ & $97.3 \mathrm{a}$ & $25.7 \mathrm{ab}$ & $190.9 \mathrm{a}$ & 98.5de & $284.1 \mathrm{a}$ \\
\hline 'Sub-Arctic Plenty' & $0.0 \mathrm{a}$ & $0.0 \mathrm{a}$ & $0.0 \mathrm{~b}$ & $0.0 \mathrm{a}$ & $435.2 \mathrm{abc}$ & $40.1 \mathrm{~b}$ \\
\hline Run $2^{\mathrm{v}}$ : & & & & & & \\
\hline 'BHN 640' & $284.6 \mathrm{a}$ & $202.8 \mathrm{a}$ & $297.6 a$ & $785.0 \mathrm{a}$ & $154.4 \mathrm{~cd}$ & $18.7 \mathrm{a}$ \\
\hline 'Florida 91' & $367.1 \mathrm{a}$ & $44.6 \mathrm{a}$ & $117.4 \mathrm{ab}$ & $529.0 \mathrm{a}$ & $0.0 \mathrm{~d}$ & $0.0 \mathrm{a}$ \\
\hline 'Glacier' & $0.0 \mathrm{~b}$ & $0.0 \mathrm{a}$ & $0.0 \mathrm{~b}$ & $0.0 \mathrm{~b}$ & $410.7 \mathrm{abc}$ & $20.9 a$ \\
\hline 'Legend' & $128.8 \mathrm{ab}$ & $171.4 \mathrm{a}$ & $145.2 \mathrm{ab}$ & $445.3 \mathrm{ab}$ & $224.4 \mathrm{bcd}$ & $0.0 \mathrm{a}$ \\
\hline 'Northern Delight' & $0.0 \mathrm{~b}$ & $0.0 \mathrm{a}$ & $0.0 \mathrm{~b}$ & $0.0 \mathrm{~b}$ & $559.2 \mathrm{a}$ & $52.5 \mathrm{a}$ \\
\hline 'Oregon Spring' & $0.0 \mathrm{~b}$ & $0.0 \mathrm{a}$ & $0.0 \mathrm{~b}$ & $0.0 \mathrm{~b}$ & $0.0 \mathrm{~d}$ & $0.0 \mathrm{a}$ \\
\hline 'Polar Beauty' & $0.0 \mathrm{~b}$ & $160.7 \mathrm{a}$ & $244.8 \mathrm{a}$ & 405.4ab & 313.3abc & $19.7 \mathrm{a}$ \\
\hline 'Santiam' & $0.0 \mathrm{~b}$ & $88.8 \mathrm{a}$ & $259.6 a$ & $348.4 \mathrm{ab}$ & $209.8 b c d$ & $256.7 \mathrm{~b}$ \\
\hline 'Siletz' & $0.0 \mathrm{~b}$ & $0.0 \mathrm{a}$ & $0.0 \mathrm{~b}$ & $0.0 \mathrm{~b}$ & $18.9 \mathrm{~d}$ & $0.0 \mathrm{a}$ \\
\hline 'Sub-Arctic Plenty' & $0.0 \mathrm{~b}$ & $0.0 \mathrm{a}$ & $0.0 \mathrm{~b}$ & $0.0 \mathrm{~b}$ & $535.0 \mathrm{ab}$ & $59.8 \mathrm{a}$ \\
\hline
\end{tabular}

${ }^{z}$ U.S. Dept. of Agriculture standard grades for fresh tomatoes; ${ }^{y}$ Total of extra-large, large, and medium fruits; x Plants were transplanted into containers on 11 May 2005 and harvested from 15 July to 19 August 2005; w Means within a column and run followed by the same letter are not significantly different according to Tukey's test at $p \leq 0.10$;

${ }^{v}$ Plants were transplanted into containers on 9 July 2005 and harvested from 30 September to 2 November 2005.

\section{Discussion}

This series of studies conducted over 15 years ago shows relevant results for the growth of high tunnel production systems in Alabama. High tunnel production has increased dramatically in the last few years across Alabama [1]. These studies were some of the first to establish that tomatoes could be grown earlier ( 3 weeks) in the spring and 12 weeks later in the fall. Prices for fresh tomatoes have increased over the last few years and most direct-marketed tomato growers receive $\$ 3.30$ up to $\$ 4.40$ per $\mathrm{kg}$ [15]. These studies demonstrate that one high tunnel (this size) can produce over \$4975 up to \$6625US per crop.

Although, the varieties used in this experiment have been replaced with improved varieties for high tunnel systems [16]. Results from this experiment suggest that some of the northern cold-tolerant varieties of tomatoes have the potential to perform equally to, or better than, 'BHN 640' and 'Florida 91' for season extension with high tunnel production, potentially allowing growers to extend the harvest season beyond that of 'BHN 640' and 'Florida 91', leading to higher potential profits. 'Polar Beauty' seems to have the best potential, while 'Legend', 'Santiam', and 'Siletz' also warrant further evaluation. 'Glacier', 'Northern Delight', 'Oregon Spring', and 'Sub-Arctic Plenty' do not appear to be suitable varieties under the conditions examined in this experiment.

Furthermore, the ability to produce tomatoes far later than normal outside production systems has been demonstrated with these varietal trial experiments. This production system has indeed grown in a large part to these studies that were conducted in southeastern. The information was disseminated via Experiment Station Field days and invited talks to commodity groups during the early years after these experiments $[17,18]$.

Author Contributions: Conceptualization, W.F., B.R., J.K., R.K., W.D.J.; methodology, W.F., E.B., formal analysis E.B.; data curation, B.R. and E.V.III, writing—original draft preparation, B.R.; writing-review and editing, W.F., E.B., W.D.J., J.K., R.K. and E.V.III; visualization, W.F.; supervision, W.F.; project administration, W.F., L.W. and E.V.III; funding acquisition, W.F. All authors have read and agreed to the published version of the manuscript. 
Funding: This research was funded by "Fruit and Vegetable Association Grants Alabama and the Alabama Agriculture Experiment Station".

Acknowledgments: The authors would like to thanks the support staff at the Wiregrass Research and Extension Center, located in Headland, AL, USA for their hard work in maintaining these experiments.

Conflicts of Interest: The authors declare no conflict of interest.

\section{References}

1. Ayanava, M. High Tunnels and Other Season Extension Techniques. Alabama Coop. Ext. Service, IPM Update Blog. 2018. Available online: https://www.aces.edu/blog/topics/ipm-farming/high-tunnels-and-other-seasonextension-techniques/ (accessed on 28 October 2020).

2. Sciabarrasi, M.; Wells, O.S. Guidelines for Using High Tunnels for Tomato Production; University of New Hampshire Cooperative Extension: Durham, NH, USA, 1999; No. 2; p. 2.

3. Wells, O.S.; Loy, J.B. Rowcovers and High Tunnels Enhance Crop Production in the Northeastern United States. Hort. Technol. 1993, 3, 92-95. [CrossRef]

4. Lamont, W.J., Jr. Overview of the Use of High Tunnels Worldwide. Hort. Technol. 2009, 19, 25-29. [CrossRef]

5. Lamont, W.J., Jr.; Orzolek, M.D.; Holcomb, E.J.; Crassweller, R.M.; Demchak, K.; Burkhart, E.; White, L.; Dye, B. Penn State High Tunnel Extension Program. Hort. Technol. 2002, 12, 732-735. [CrossRef]

6. Penn State Center for Plasticulture. Plastic Mulches. 2008. Available online: http://plasticulture.cas.psu.edu/ P-mulch.html (accessed on 15 March 2009).

7. Sanders, P. Evaluation of High Tunnel Production of Tomatoes and Strawberries in Central Alabama. Master's Thesis, Auburn University, Auburn, AL, USA, 2006.

8. Kemble, J.M.; Tyson, T.W.; Curtis, L.M. Guide to Commercial Staked Tomato Production in Alabama. Alabama Cooperative. Extension System, ANR-1156. 2004. Available online: https://ssl.acesag.auburn.edu/ pubs/docs/A/ANR-1156/ANR-1156-archive.pdf (accessed on 16 July 2012).

9. Spaw, M. Tomato Production: High Tunnel vs. Field Grown Tomato Culture. 2007. Available online: http://www.hightunnels.org/ForEducators/TomatoProduction/Versus.htm (accessed on 15 March 2008).

10. Wells, O.S. Guidelines for Using High Tunnels for Tomato Production. Univ. New Hamps. Coop. Ext. Publ. 1991, 3, 92-95.

11. Maynard, D.N.; Hochmuth, G.J. Knott's Handbook for Vegetable Growers, 4th ed.; Wiley: New York, NY, USA, 1997.

12. White, L.; Burkhart, E.; Lamont, W.J., Jr.; Orzolek, M.D. 2003 High. Tunnel Production Manual; Penn State Center for Plasticulture: State College, PA, USA, 2003.

13. U.S. Department of Agriculture. United States Standards for Grades of Fresh Tomatoes. 1997. Available online: http://www.ams.usda.gov/AMSv1.0/getfile?dDocName=STELPRDC5050331 (accessed on 15 March 2009).

14. USDA/Federal State Market News. Atlanta Terminal Market Prices. 2020. Available online: https://www.ams. usda.gov/mnreports/aj_fv020.txt (accessed on 25 November 2020).

15. Rodriguez, O.; Torres, A. Are Local Tomatoes More Expensive? A Comparison of Price Trends between Farmers Markets and Grocery Stores. Purdue University Extension Service, Horticulture \& Landscape Architecture. Publication: HO-300-W. 2018. Available online: https://www.extension.purdue.edu/extmedia/ $\mathrm{HO} / \mathrm{HO}-300-W . p d f$ (accessed on 27 November 2020).

16. Johnny's Select Seeds. Top-15 Tomatoes for Hoophouse \& High Tunnel Production. 2020. Available online: https: //www.johnnyseeds.com/growers-library/vegetables/tomatoes-best-varieties-high-tunnel-production.html (accessed on 28 October 2020).

17. Foshee, W.G., III; Reeder, B.E.; Kessler, R.J., Jr.; Wells, L.W.; Kemble, J.M.; Vinson, E.L.; Boozer, R.T.; Dozier, W.A., Jr. High tunnel production of tomatoes and snapdragons in southeast Alabama. HortScience 2006, 41, 507. [CrossRef]

18. Foshee, W. Wiregrass Experiment Station Field Day-High Tunnel Research Initiative for the Wiregrass; Wiregrass Research and Extension Center: Headland, AL, USA, 2005.

Publisher's Note: MDPI stays neutral with regard to jurisdictional claims in published maps and institutional affiliations. 